\title{
Linguistic Performance of West Sumatera Executive Officials in Communicating via Facebook
}

\author{
Novia Juita, Ermanto, Ngusman Abdul Manaf \\ Fakultas Bahasa dan Seni, Universitas Negeri Padang, Indonesia \\ noviajuita@ymail.com
}

\begin{abstract}
This article was written to describe the performance of Indonesian language from executive officials in social media, Facebook. The issues discussed focused on two things, namely (1) the structure of the sentence, and (2) the choice of vocabulary. Data source was the written text of executive officials in their Facebook. The data was collected by downloading the writing texts of the executive officials through Youtube. Data were analyzed qualitatively by content analysis method using linguistic theory related to sentence structure and diction (syntax). The results obtained were: first, the sentence structure used in the form of complex sentence, elliptical sentence, and inverted sentence; second, the vocabulary (diction) used in the form of Indonesian vocabulary (appropriate and inappropriate) and the vocabulary of regional and foreign languages.
\end{abstract}

Keywords---performance, structure, diction, executive officials, Facebook

\section{INTRODUCTION}

Studies related to the language competence of Indonesian public officials, especially executive officers have done a number of researchers. One of the related studies was conducted by Luhukay $(2007$, p. 70$)$ which examined the text of President Yudhoyono's speech by using rhetorical approach, especially through Aristotle's approach. In conclusion, President SBY chooses the right vocabulary (diction) and uses the language effectively to convey the message to the listener. Furthermore, Subali (2009, p. 25) examined Sukarno in terms of linguistic phenomena and concluded that Sukarno speaks and communicates his thoughts to the public never be separated from certain motives and goals. Sukarno's use of language is more functional than formal.

For research on the linguistic performance of executive officers, it has been conducted by Setiana, Anggun; Munaris and Muhammad Fuad (2015, p. 1-12) in examining the linguistic aspects of Jokowi in the debates of the 2014 2019 Presidential Candidate. In conclusion, Jokowi utilizes several language styles such as repetition, hyperbole, metaphor, and personification. Jokowi also performs a variety of official languages, business, familiar, literature, idiolect, and sosiolect. In addition, Asmara (2016, p.v379-388) also reviewed the linguistic strategy of President Jokowi in instilling the ideology and manifesto of government. In his efforts to inculcate the ideology and manifesto of government, President Jokowi used a vocabulary and stylistic strategy that has a connection with the term maritime and work-oriented. Jokowi sticks to his leadership patron which is identical to the term blusukan (impromptu visits) but later packed with a more positive diction specifically in the jargon work, work, and work.

Next, Arofah (2015) researched on YouTube as a media for clarification and statements of political figures. The findings conclude that political communicators use YouTube as an alternative medium and supplements for mainstream media for political clarification. The purpose of using Youtube is to form a positive image and influence public opinion. However, the clarification made by the official on YouTube was not able to form a positive image and change public opinion.

Another study conducted by Sartini (2015, p. 171-179) examines language and public image as a language strategy in political discourse. The conclusion is that language has tremendous power for political purposes, one of which is to shape the image of a political figure. The linguistic strategies used in the political discourse found are implicature, euphemism, lexicalization, grammatical structure, metaphor, and hyperbolism. The use of language in political discourse does not merely convey information, but there is motivation and goals to be achieved. Selection of words, sentences, and certain grammatical patterns is not seen as a mere grammatical or linguistic technical matter, but it is an expression of ideology, that is, attempts to form a public opinion, to affirm, and to justify their own group and to isolate the other groups.

In particular, research on the language performance of government officials in various communication events using social media in Indonesia has been done by several researchers as follows: Wulansari (2014) concludes that the use of social media especially Twitter, for the public interest and for political communication by political elites, regional leaders and state officials is increasingly popular. For example, Kamil (Mayor of Bandung city) uses social media Twitter for the socialization and transparency of his work programs. Not only that, Kamil also uses Twitter to campaign on issues of political participation, environment, health to the preservation of traditional culture. Meanwhile, Budiyono (2016) stated that social media Facebook can also be used to convey the vision and mission of a candidate, 
and allow the audience to submit feedback directly. Negative responses from the public appear in the form of harsh words and even SARA (ethnic, religious, racial and intergroup) things. Thus, a social media ethic needs to be built for more polite communication.

Furthermore, Suardi (2016) concluded that politicians can rally support through social media too. However, politicians can also get attacks from other parties who are not sympathetic through that social media. Suherman's research (2016) found some facts about why Kamil uses social media like Facebook, Twitter and Instagram. Kamil has a vision to give and share as many benefits as possible for the people of Bandung through social media and it is the result of a reflection of the belief that he believes in. These three social media have a special role in government communication run by Kamil and City Government of Bandung as a whole, precisely, to simplify and shorten the flow of government bureaucracy.

Relying on the findings and inputs from previous research, it can be further explained that Indonesian language performance and politeness communicate in various social media today has become an important aspect for the success of officials in Indonesia. Therefore, the study related to the public speaking performance of these public officials should continue, and the results should be widely published. This study is one of the results of the research as intended.

\section{METHOD}

This article is one of the research's outcomes on language performance by executive officers in West Sumatera. The source of data came from the Facebook account of executive officers consisting of governors, deputy governors, regents and mayors. Data were collected by downloading text from Facebook accounts used by these officials to communicate with the public. Data were analyzed qualitatively through content analysis method and also by considering syntactic and diction theory.

\section{A. Sentence Structure}

\section{FINDING AND DISCUSSION}

Results of data analysis about the structure (use of sentences) indicates that the executive officers in West Sumatera use varied sentences. There is a long, complete sentence, long sentences, ambiguous / incomplete structure. There is also a simple, but complete sentence; simple and incomplete sentences. The description will be explained as follows.

\section{Complex Sentence}

The complex sentence consists of more than one clause (pattern) and has a complete functional. This kind of sentence structure is predominantly found in this research. Here are some of the findings.

(1) Setelah melalui seleksi yang cukup ketat, saya mewakili rakyat Sumbar insya Allah akan menerima Tanda Kehormatan Gelar Tanda Jasa Satya Lencana Pembangunan bidang Pangan dari Presiden RI di Pembukaan Penas Tani XV di Banda Aceh. (23/2-8)

(2) Menjelang santap Sahur, mari kita juga senantiasa bersyukur kepada Allah, apapun kondisi yang ada, sembari berharap Allah jauhkan kita dari Musibah, dan saya pribadi berharap Allah berikan kemampuan untuk selalu melayani segenap Warga Kota Padang maupun para pendatang yang hadir di Padang Kota Tercinta. (678/235105)

The analysis is as follows.

Data (1) is a long and complex sentence. This sentence consists of several clauses. There is a main clause (main clause) and an additional clause (sub-clause). The main clauses are: Saya akan menerima penghargaan/ I will received the recognition $(\mathrm{I}=\mathrm{S}$, will receive $=\mathrm{P}$, and the recognition $=\mathrm{O})$; (representing $(\mathrm{P})$ the people of West Sumatra $(\mathrm{O})$ as an additional element of $\mathrm{S}$ element also in the form of clauses) After going through a tight selection (Adv); Honor Sign of Satya Badge for Food Development (Adv.); from the President of the Republic of Indonesia in the Opening of the XV Farmer's National Week in Banda Aceh (Adv).

Similar cases can also be observed in the data (2) with the analysis as follows.

The main clause of this sentence consists of two equivalent clauses, : (1) we thank God, and (2) I hope God gives us a strength. Meanwhile, other elements such as changeable information elements (Adv) and additional information for certain functional elements.

Similar cases can also be observed in the following data

(3) Baik dalam penyusunan Rencana Pembangunan Jangka Menengah Daerah (RPJMD) dan APBD Provinsi, anggaran untuk peningkatan kualitas pendidikan dan peningkatan output pendidikan kami masukkan dalam daftar prioritas. (3/4-2) 
(4) Jalan yang akan menghubungkan Kecamatan Siberut Selatan dan Kecamatan Siberut Tengah, progres yang begitu baik, semoga pembangunan jalan untuk akses masyarakat dapat berjalan sesuai dengan rencana. $(503 / 395-115)$

(5) Alhamdulillah hari ini, dalam Rapat Koordinasi Nasional (Rakornas) Bidang Kemaritiman di Jakarta, utusan Pemprov Sumatera Barat yang dipimpin Wakil Gubernur, Bp Nasrul Abit bisa melobi Menteri KKP, Susi Pudjiastuti memberikan perpanjangan izin melaut bagi nelayan kapal bagan Sumbar, yang semula berakhir Juni 2017, menjadi Desember 2017. (28/29-10)

(6) Ucapan terima kasih kepada seluruh insan pers yang selalu berupaya memberikan pencerdasan, pendidikan dan pengetahuan serta berupaya bersama meningkatkan martabat bangsa khususnya bagi masyarakat Kabupaten Kepulauan Mentawai. (515/413-123)

The above sentences are examples of long sentences that are not confusing. Those sentences are still in the category of effective sentences. Here is an example of data for long sentences that are considered confusing (ineffective).

(7) Maka, pada kesempatan pertama, atas nama Pemerintah Provinsi Sumatera Barat saya ucapkan selamat datang warga Pesisir Selatan yang tergabung dalam IKPS Pabasko disertai ucapan "Selamat Hari Raya Idul Fitri 1438 $H$ ” semoga dihari ini kita dapat berkumpul dan bersilaturahmi dalam keadaan yang fitri. (348/435-143)

(8) Selamat menikamati Indahnya Kota berhawa sejuk ini, selamat menikmati kuliner yang enak dan terimakasih atas perhatian Klub Datsun Riser Expedition kepada dunia penididikan kota Padang Panjang dimana pada kesempatan itu memberikan bantuan buku buku pendidikan ke SDN 07 Kelurahan Ekor Lubuk. (620/113-49)

(9) Ketika tiba saat perpisahan, jangan kalian berduka, sebab apa yang kalian kasihi darinya mungkin akan nampak lebih cemerlang dari kejauhan seperti gunung yang tampak lebih agung terlihat dari padang dan daratan. (337-136)

(10) Jalan yang akan menghubungkan Kecamatan Siberut Selatan dan Kecamatan Siberut Tengah, progres yang begitu baik, semoga pembangunan jalan untuk akses masyarakat dapat berjalan sesuai dengan rencana. (395115)

\section{Sentence without subject}

From the results of data analysis, sentences without subject (subjectless) are also widely spoken by executive officials. Here are some sample data.

(11) Memberikan tausyiah dan makan bersama jamaah subuh di mesjid agung Nurul iman. (748/488-186)

(12) Silaturrahim lapau bersama Alhudri Dt Rky Mulie dan masyarakat Talawi. (622/159-68)

(13) Tadi sore (Jum'at, 7 Okt 16) diterima Kepala Badan Pengembangan Infrastuktur Wilayah (BPIW) Kementerian PUPR, Bapak Ridho Matari Ichwan. (64-27)

(14) Memberikan Bantuan dari Dinas DKP Prov berupa GPS, Betor dan Bibit ikan yg di berikan secara simbolis. (376-127)

(15) Meninjau persiapan panen perdana bawang Tuk-Tuk bersama Perwakilan PT Panah Merah di Balai Joriang. (189-86)

(16) Memeriksa dan memberikan pengarahan kepada ASN Kecamatan Padang Utara. $(656 / 205-94)$

The six examples of data above (11-16) are sentences without subject. The absence of this subject is more due to the context. These sentences are written on Facebook which is usually accompanied by tagged photos. This aspect of narrative photos is more important. Meanwhile, the texts only repeat the explanation that has been submitted by the photo. 


\section{Inverted Sentence}

The inverted sentence is a sentence with pattern P-S. The use of this pattern is for emphasis (focusing). Sentences with inverted pattern is quite widely used by the officials in their Facebook accounts. A number of inversion sentence data can be observed in the following example.

(17) Selamat Hari Pendidikan Nasional (2-2)

(18) Maju Pendidikannya, Maju Negerinya (9-2)

(19) Hangat dalam perut, hangat dalam persahabatan. (342-113)

(20) Bantulah sesama, selagi kita masih diberi kesempatan untuk bisa membantu... (482-162)

(21) Ulurkanlah tangan dan jangan pernah merasa rugi dan berat hati untuk membantu... (483-162)

(22) Masih ada potensi 749 Mega Watt (MW) yang menunggu investor. (85-18)

\section{Elliptical Sentence}

Elliptical sentence is a shorter form of sentence which some words have been omitted, but it retains the same meaning. In this case, the elliptical sentences are found in the text used to describe the photos. Data on the use of elliptical sentences can be seen in the following examples.

(23) Rapat Paripurna Istimewa DPRD Sumbar. (14-5)

(24) Nasi Tumpeng dari BMI. (17-6)

(25) Insya Allah pada hari Sabtu, 6 Mei 2017. (25-8)

(26) Membuka Raker Pertama "Gonjong Limo" di Pekanbaru. (46-15)

(27) Sholat Subuh dan Kuliah Subuh di Banda Aceh. (33-12)

(28) Para penjaga NKRI dari berbagai pelosok negeri. (147-40)

\section{B. Wording Performance by Executive Officers of West Sumatra in their Facebook}

Wording performance in this case relates to the accuracy, propriety, and aptness of the vocabulary used to express something. In connection with that reason, a number of cases are found as follows.

\section{Unsuitable wording}

There are a number of data found in connection with the inaccuracy of word-choice. The inaccuracy of the word choice because the word used is not standard and the meaning of the word is not correct. In addition, a number of words are not found in the dictionary. Here are some data that have been identified:

(1) Pada malam Silaturahim Milad ke-25 PT. Bank Muamalat Indonesia, Tbk memberikan saya Penghargaan Nasabah Setia Bank Muamalat Indonesia. (19/20-7)

(2) Wagub Sumbar H. Nasrul Abit Dt. Malintang Panai beserta Tim Safari Ramadhan Pemprov Sumbar berbuka puasa bersama pengurus Mesjid, masyarakat setempat serta unsur Muspika, sebelum melaksanakan Safari Ramadhan Rabu 21 Juni 2017 di Mesjid Darussalam Kelurahan Bungus Selatan, Kecamatan Bungus Teluk Kabuang, Kota Padang. (299/370-126)

(3) Dengan program Bukapalitar, diharapkan percepatan pembangunan akan segera terealisir. (298/347-114)

(4) Dengan banyaknya pembangunan jembatan dan jalan di Sumbar ke depannya, kita berharap percepatan koneksitas jalan cepat terwujud, termasuk jalur Trans Sumatera Padang - Bukittinggi - Pekanbaru, dan jalur lintas Selatan dan Utara (132/133-35)

(5) Pesantren Ramadhan yang dilaksanakan di sekolah, selain mengisi waktu di bulan ramadhan, juga sebagai bagian integral dalam pembentukan kharakter siswa dalam pembangunan SDM bangsa. (248/249-74)

(6) Sekaligus melestarian kemanunggalan TNI dan rakyat serta menerapkan budaya gotong royong kedekatan TNI dengan masyarakat. (328/408-134) 
(7) Pembangunan fisik dapat membuka jalan keterisoliran dengan daerah lain menuju pusat pertumbuhan ekonomi di daerah. (330/410-134)

(8) Selamat Ulang Tahun yang ke 59 Bapak H. Ali Asmar, Sekda Provinsi Sumatera Barat. Semoga dikaruniai usia yang baroqah serta kesehatan yang prima oleh Allah SWT. (335/416-137)

(9) Dalam sambutannya Wagub berharap, restoran yang secara khusus menyajikan sejumlah panganan otentik khas Sumatera Barat sebagai menunya ini dapat berkontribusi bagi sektor pariwisata Sumatera Barat di bidang kulinari. (336/419-138)

(10) Dalam rangka pembangunan pariwisata Sumbar itu pula Wagub Sumbar berharap kehadiran Katagiaan Resto dengan daftar harga menu yang terpampang jelas dan besar di salah satu dinding ruangannya dapat memperbaiki citra rumah makan di Sumbar yang kadung rusak di dunia maya akibat ulah sejumlah oknum pengusaha rumah makan yang tidak transparan dalam harga dan mamakuak konsumen. (420-138)

(11) Menyangkut hal ini Wagub kemudian melontarkan sebuah kelakar sarkas untuk gambarkan citra rumah makan Sumbar yang terbentuk di masyarakat, diceritakannya, "ada teman di Ibukota bilang, syarat jadi pegawai rumah makan Padang itu tidak bisa berhitung, hitung harga per menu puluhan ribu, nanti total yang harus dibayar jadi beda." (338/421-138)

(12) Barusan diberitahu Kementerian Agama. (383/5-2)

(13) Target 2018/2019 semuanya jalan lingkungan kita sudah terbetonisasi. (747/487-185)

(14) Mari ramaikan mesjid dengan kegiatan ibadah di bulan suci Ramadhan (736/469-178)

(15) Dari itu pada hakekatnya semua manusia yang hidup didunia ini adalah seorang pemimpin, minimal memimpin dirinya sendiri, memenejemen hatinya karana salah satu tugas seorang pemimpin adalah "memenejemen”. $(723 / 343-137)$

(16) Mujahid tak keseorangan karena dirantai dengan ukhuwah (713/332-136)

(17) Memasuki bulan Ramadhan dan antisipasi banjir, dihimbau warga seluruh kelurahan untuk melaksanakan Goro baik di mesjid/mushala dan saluran air. (741/475-182)

The application of words like silaturahim, mesjid, terealisir, kharakter, keterisoliran, hakekat, memenejemen, and baroqah are unofficial. The standard forms are silaturahmi, masjid, terealisasi, karakter, keterisolasian, hakikat, memanajemen, and barokah. Next, several words like kulinari, kesorangan, and kadung are unavailable in the dictionary. These three words may be miswritten. Similar to words like terbetonisasi, sarkas, and barusan. The correct writing for all three words is terbetoni, sarkasme, and baru saja.

\section{Regional Vocabulary}

The results of data analysis shows that regional vocabularies are widely used by the executive officers in communicating on their Facebook account. The data containing this case can be viewed in the following examples.

(1) Sumatera Barat dalam sejarahnya hingga kini banyak mencetak dan bersumbangsih pada hadirnya kaum cadiak pandai, yang berprestasi bagi negeri ini. (6/7-2)

(2) Tandanya orang Minang, dima bumi dipijak, di situ langik dijunjuang. (55/56-15)

(3) Kami sangat berterima kasih kepada ibu Aswita sekeluarga yang telah membuat kami hampir seminggu di negeri orang, lapeh taragak dengan masakan Minang. (217/218-64)

(4) Kami mempersilahkan bagi dunsanak jika berkenan untuk singgah bersilaturrahim. Mohon maaf jika ada yang tak berkesempatan untuk masuk, jika sudah penuh. (265/297-96)

(5) Salam takzim silaturrahim untuk dunsanak dan masyarakat semuanya. (266/298-96) 
(6) Rabu, 28 Juni 2017 Wagub Sumbar Drs. H. Nasrul Abit Dt. Malintang Panai menyambut dan sekaligus membuka secara resmi keseluruhan acara pulang basamo nusantara, Persatuan Keluarga Paninggahan (KKP) di Paninggahan Kab. Solok. (312/389-132)

(7) Dalam rangka pembangunan pariwisata Sumbar itu pula Wagub Sumbar berharap kehadiran Katagiaan Resto dengan daftar harga menu yang terpampang jelas dan besar di salah satu dinding ruangannya dapat memperbaiki citra rumah makan di Sumbar yang kadang rusak di dunia maya akibat ulah sejumlah oknum pengusaha rumah makan yang tidak transparan dalam harga dan mamakuak konsumen. (420-138)

The italicized words in the example data above is the vocabulary from the local language (Minangkabau). The vocabulary can still be used, but the writing must be in accordance with rules of EBI (Indonesian Spelling). Thus, The vocabulary should be italicized. Another way that can be used is to write the equivalent word in Indonesian.

\section{Foreign Vocabulary}

The vocabulary of foreign languages, especially English and Arabic is found quite vast. The use of foreign language vocabulary is permitted as long as in accordance with EBI guidelines. This phenomenon can be seen in the following examples.

(1) Bersama jajaran OPD dan Kapolda melakukan teleconference dengan Kapolri, Mendagri, Mentan, Mendag, dan Kabulog terkait persiapan penanganan alur distribusi barang dan jasa serta stabilitas harga menjelang Ramadhan. (11/12-4)

(2) Jumat kemarin (12/5/17) saya membuka acara Workshop Social Entrepreneurship Penguatan Lembaga LKKS Sumatera Barat. (103/104-26)

(3) Bagi Sumatera Barat, pembangunan jembatan dan jalan menjadi lebih efisien dengan adanya support pabrik yang ada di Sumbar.( 131/132-35)

(4) Saya hari ini menerima mahasiswa asal Irlandia dan Meksiko, yang mengikuti program Student Exchange di Universitas Andalas. (287/331-108)

(5) Saya didaulat para direksi dan komisaris Bank Muamalat Indonesia menerima nasi tumpeng pada acara puncak milad ke-25 PT. Bank Muamalat Indonesia, Tbk di Hotel The Rizt-Carlton, Mega Kuningan Jakarta pada malam ini (17/18-6)

(6) Alhamdulillah nikmatnya berthalabul 'ilmi hari ini bersama-sama jamaah di Masjid Raya Sumatera Barat. $(112-29)$

(7) Semoga ranah Minang senantiasa dilindungi Allah dan dicurahkan keberkahan dengan hadirnya para ulama ke tanah kami dan keinginan kuat masyarakat untuk taqarrub 'ilallah (114-29)

(8) Barakallahu lakum wa baraka 'alaikum wa jama'a bainakum fii khaiiir, semoga kedua mempelai memperoleh lindungan dan bimbingan dari Allah, dalam menempuh mahligai pernikahan ini, menuju keluarga sakinah, mawaddah wa rahmah. (120-31)

(9) Alhamdulillah tahun ini siswa SMP IT Adzkia yang berhasil menuntaskan Hafidzul Qur'an hingga 6juz ada 2 siswa, dan 1-5 juz sebanyak 68 siswa. $(156 / 157-43)$

(10) Alhamdulillah, sore ini saya menghadiri acara wisuda daurah Tahfidzul Qur'an tingkat SMP dan SMA, yang diikuti siswa dari berbagai kota di Sumatera Barat dan Jambi. (259/279-88)

The italicized word above is foreign vocabulary whose writing is not in accordance with EBI guidelines. For that, it needs to be revised. There are two ways to improve that mistake. First, by searching its equivalent in the Indonesian language. Secondly, by using the original language, but the writing must be in italics form. The word teleconference has the equivalent of the term in Indonesian, which is long-distance talk'; Student Exchange equivalent to student exchange'; milad is equivalent to birthday'; or retain the original form but in italics like taqarrub 'ilallah, and Barakallaadalahhu lakum wa baraka 'alaikum wa jama'a bainakum fii khaiiir. 


\section{CONCLUSION AND RECOMMENDATION}

This article discusses two fundamental things; sentence structure and wording usage by public officials (executives) of West Sumatra in Facebook. In accordance with the structure of the sentence, the executive officials in West Sumatra used sentences with varying structures and patterns. There are sentences with complete and complex structure, elliptical sentences, sentences without subject and inverted sentences. For wording performance, executive officers in West Sumatra dominantly chose Indonesian, foreign and regional vocabulary. In addition, the inappropriate writing of words were still also found.

Although these public officials use the Indonesian language in an informal situation exactly in social media communication, it is hoped that it should continue to adapt and adhere to rules of writing in Indonesian language. This is very important to remember so that the messages conveyed by public officials are not multi-interpretation.

\section{References}

Anshari, F. (2013). Komunikasi Politik di Era Media Sosial”. Jurnal Komunikasi, 8 (1) Oktober 2013.

Arofah, K. (2015). Ұoutube Sebagai Media Klarifikasi dan Pernyataan Tokoh Politik”. Jurnal Ilmu Komunikasi, 13 (2) Mei - Agustus 2015, halaman 111-123.

Asmara, R. (2016). Strategi Kebahasaan Presiden Jokowi dalam Menanamkan Ideologi dan Manifesto Pemerintahan`. LITERA 15 (2), Oktober 2016 hal 379-388.

Budiyono. (2016). “ Media Sosial dan Komunikasi Politik: Media Sosial sebagai Komunikasi Politik Menjelang PILKADA DKI JAKARTA 2017”. Jurnal Komunikasi 11 (1), Oktober 2016

Corry, WA. (2009). —Etika Berkomunikasi dalam Penyampaian Aspirasi”. Jurnal Komunikasi Universitas Tarumanagara, Tahun I/01/2009 hal 14-18.

Luhukay, MS. (2007). Presiden SBY dan Politik Pencitraan: Analisis Teks Pidato Presiden SBY dengan Pendekatan Retorika Aristoteles" Jurnal Ilmiah SCRIPTURA 1 (2) Juli 2007.

Mujianto, G. (2013). Tuturan Pejabat Negara Dalam Berita Korupsi” Pada Media Massa Cetak. Jurnal Humanity 8 (2) Maret 2013 p. $13-20$.

Mustakim. (2015). Bentuk dan pilihan kata. Jakarta: Badan Pengembangan dan Pembinaan Bahasa Kemendikbud.

Peraturan Presiden Republik Indonesia Nomor 16 Tahun 2010 tentang Keprotokolan

Pranowo. (2015). Unsur Intralingual dan Ekstralingual Sebagai Penanda Daya Bahasa dan Nilai Rasa Bahasa dalam Kesantunan Berkomunikasi. Jurnal Adabiyyāt, 14 (2), Desember 2015 Hal 192—225.

Purnomo, B. (2011). Tourism-service language: acrosscultural perspective on politeness. Humaniora, 23 (2). Juni 2011, 185-198.

Pusvita, WD. (2016). Kesantunan Maksim Dan Imperatif Dalam Mata Najwa Episode — Kabibi Hari Ini’'(Sebuah Kajian Pragmatik). Prosiding International Seminar Prasasti III.

Rohali. (2011). Kesantunan Berbahasa Sebagai Pilar Pendidikan Karakter: Perspektif Sosiopragmatik". Jurnal Pendidikan Karakter, Tahun I, Nomor 1, Oktober 2011 p. 76 -97.

Sartini, NW. (2015). Bahasa Dan Pencitraan: Strategi Kebahasaan Dalam Wacana Politik". JURNAL TUTUR 1(2) Agustus 2015 p. $171-179$.

Sasangka, SSTW. (2015). Kalimat. Jakarta: Badan Pengembangan dan Pembinaan Bahasa Kemendikbud.

Setiana, A., Munaris \& M. Fuad. (2015). Aspek Kebahasaan Jokowi Pada Debat Calon Presiden dan Kegunaannya dalam Pembelajaran”.Jurnal Kata (Bahasa, Sastra, dan Pembelajarannya) April 2015 Prodi Pendidikan Bahasa dan Sastra Indonesia FKIP Universitas Lampung p. 1-12.

Sosiowati, IGAG. (2013). -Kesantunan Bahasa Politisi dalam Talk Show di Metro TV’. Disertasi Program Doktor Program Studi Linguistik Program Pascasarjana, Universitas Udayana Denpasar.

Suardi. (2016). Antara Media Sosial dalam Komunikasi Politik”. Jurnal RISALAH, 27 (2), Desember 2016 p. $82-86$

Subali, E. (2009). "Bung Karno, Fenomena Kebahasaan Dan Lahirnya Indonesia Merdeka”. Jurnal Sosial Humaniora, 2 (1) 1, Juni 2009 Hal 15-28.

Subroto, DE. (1992). Pengantar metode penelitian struktural. Surakarta: Sebelas Maret University Press.

Sudaryanto. (1993). Metode dan aneka teknik analisis bahasa: Pengantar penelitian wahana kebudayaan secara linguistis. Yogyakarta: Duta Wacana University Press.

Suherman, M \& H. Munandar. (2016). Aktivitas Komunikasi Pemerintahan Ridwan Kamil di Media Sosial”. Prosiding Hubungan Masyarakat 2 (1) 1, Tahun 2016

Tabroni, R. (2017). Komunikasi Politik Mohammad Natsir”. Communicatus: Jurnal Ilmu Komunikasi. 1 (1) JanuariJuni 2017 p. 45-65. Fakultas Dakwah dan Komunikasi UIN Sunan Gunung Djati Bandung.

Tim Pengembang Pedoman Bahasa Indonesia. (2016). Pedoman Umum Ejaan Bahasa Indonesia. Jakarta: Badan Pengembangan dan Pembinaan Bahasa Kemendikbud

Undang-Undang Republik Indonesia Nomor 24 Tahun 2009 tentang Bendera, Bahasa, Dan Lambang Negara, Serta Lagu Kebangsaan. 
Widiatmoko, B. (2007). Analisis Bahasa Politik Pejabat Publik Indonesia Berdasarkan Tinjauan Filsafat Nilai”. Jurnal Paradigma 8 (1) tahun 2007 p. 119-128.

Widyawari, CPGM. (2016). Representasi Ideologi Dalam Tuturan Santun Para Pejabat Negara Pada Talk Show Mata Najwa". Seloka: Jurnal Pendidikan Bahasa dan Sastra Indonesia SELOKA 5 (1) (2016). Hal 1-11.

Wulansari, I. (2014). Artikulasi Komunikasi Politik Ridwan Kamil dalam Media Sosial Twitter-Jurnal Universitas Multimedia Nusantara 6 (2) Desember 2014.

Yasdanfar, S., \& Bonyadi. A. (2016). Request strategies in everyday interaction of Persian and English Persian. SAGE open. Ocktober-December 2016, 1-11.

Yusri, YH. \& Riskawati. (2016). Representasi Tindak Tutur Calon Gubernur Sulawesi Selatan: Analisis Wacana Kesopanan Berbahasa”. Makara, sosial humaniora, 16 (2), Desember 2012 p. 116-122. 